\title{
The effect of nutrients on feed intake in ruminants
}

\author{
P. Faverdin \\ INRA, Station de recherche sur la vache laitière, 35590 Saint-Gilles, France
}

\begin{abstract}
The purpose of the present review is to examine the role played by nutrients in controlling feed intake in ruminants, in light of their particular anatomical, physiological, nutritional and behavioural characteristics. The ration is first digested in the rumen for several hours by microbial fermentation. Volatile fatty acids, which constitute $50-75 \%$ of a ruminant's energy supply, considerably depress feed intake when administered by short-term infusion into the rumen. However, this effect seems to be largely due to osmolarity problems. Only propionate seems to have a specific action, unrelated to osmolarity, in the mesenteric or portal veins. Nitrogenous nutrients have little short-term effect on feed intake, except when there is excess $\mathrm{NH}_{3}$ in the rumen. Metabolic cues from intestinal digestion, particularly of glucose and starch, have very little shortor long-term influence in controlling feed intake, in comparison with rumen digestion cues. However, the short-term responses in feeding behaviour do not always reflect longer-term effects on feed intake control. The effects of volatile fatty acid infusion on feed intake are much less significant over the long term, except in the case of propionate. The nutrients required for good microbial activity (proteins in the rumen) generally promote feed intake, whereas nutrients that disrupt rumen functioning (lipids) reduce feed intake. After a learning period, preferences are always governed by a tendency toward optimum rumen functioning, rather than by animal nutritional requirements, although the two factors are not independent. Ruminants, due to their particular anatomical and nutritional characteristics, have, in the course of their evolution, developed specific feed intake control mechanisms based on nutritional cues.
\end{abstract}

\section{Résumé}

L'objet de cette revue est d'étudier le rôle des nutriments dans les mécanismes de contrôle de la prise alimentaire chez les ruminants, en tenant compte de leurs particularités anatomiques, physiologiques, nutritionnelles et comportementales. La digestion de la ration se déroule d'abord pendant de nombreuses heures dans le rumen par fermentation des aliments par des microbes. Les acides gras volatils, qui constituent $50-75 \%$ des nutriments énergétiques d'un ruminant, présentent des effets rassasiants marqués lorsqu'ils sont perfusés dans le rumen. Cependant, ces effets semblent liés dans une large mesure à des problèmes d'osmolarité. Seul le propionate semble agir avec une action spécifique autre que l'osmolarité au niveau des veines mésentériques ou porte. Les nutriments azotés ont peu d'effet à court terme sur la prise alimentaire, excepté en cas d'excès d'ammoniac du rumen. Les signaux métaboliques provenant de l'absorption intestinale, en particulier le glucose ou l'amidon, ont très peu d'effet, à court ou long terme, dans le contrôle de la prise d'aliment comparativement aux signaux provenant de la digestion ruminale. Mais les réponses observées à court terme dans le contrôle de la prise alimentaire ne présagent pas toujours des effets à plus long terme dans la régulation des quantités ingérées. Les effets des acides gras volatils sur les quantités ingérées sont beaucoup moins nets à long terme, sauf pour le propionate. Les nutriments indispensables au bon fonctionnement de l'activité microbienne (protéines dans le rumen) ont des effets favorables sur l'ingestion alors que les nutriments qui perturbent le fonctionnement du rumen (lipides) diminuent les quantités ingérées. Après apprentissage, les choix alimentaires s'orientent toujours vers une recherche d'un fonctionnement optimal du rumen plus que vers une bonne adéquation des apports aux besoins de l'animal, même si les deux ne sont pas indépendants. Les ruminants présentent donc, de par leurs spécificités anatomique et nutritionnelle, des adaptations originales dans les mécanismes de régulation des quantités ingérées à partir des signaux nutritionnels.

\section{Ruminants: Feeding behaviour: Volatile fatty acids}

\footnotetext{
Abbreviation: VFA, volatile fatty acids.

Corresponding author: Dr P. Faverdin, fax +33 299285 101, email faverdin@ st-gilles.rennes.inra.fr
} 
Ruminants play a significant role in ecosystems, since they mainly eat plants. To get the most benefit from roughage, the ruminant digestive system includes forestomachs known as the reticulum, rumen and omasum, which constitute a veritable continuous-process digester. Ruminants use the various fermentation products as their main source of nutrition. Feeding behaviour may be separated into two distinct components: feed intake and rumination (Jarrige et al. 1995), which are highly influenced by the fact that feed consists primarily of roughage. Feeding is generally of very long duration (from 5 to $11 \mathrm{~h} / \mathrm{d}$ ), particularly when ruminants are in a natural environment and must find food for themselves. This extensive use of roughage has resulted in various specific characteristics relating to eating behaviour, digestion and metabolism, which have implications for feed intake control mechanisms.

In ruminants, the activity of eating occupies most of the daytime. Changes in feed intake kinetics and particularly in feed intake rate over time make it possible to study the development of satiation mechanisms. The presence of feed in the rumen is an essential phase of the satiation process. Removing boluses during feed intake almost doubles the size of a normal meal (Campling \& Balch, 1961). Although rumen fill plays a role in the satiation process (Forbes, 1995), the biochemical cues produced by fermentation may also be used to control feed intake. Digestion products during the post-feeding phase may, in the short term, send signals to the central nervous system through various nervous, metabolic or hormonal channels, and may also contribute to the satiation process during feeding. Their long-term effect is more complex, since a nutrient may cause premature satiation, without however ultimately reducing feed intake. The stimulation of reward mechanisms or effects on the metabolism may also have a longer-term impact on the animal's appetite.

The purpose of the present review is to show how nutrients are involved in feed intake control mechanisms in ruminants, in light of their particular anatomical physiological, nutritional and behavioural characteristics. It will deal specifically with the effects of major macronutrients on feed intake, examining separately energy nutrients and nitrogenous nutrients. First, the short-term effects of nutrients on appetite will be examined in both feeding and post-feeding satiation processes. An attempt will then be made to study the medium- and long-term effects of nutrients on feed intake. These mechanisms are more complex, but more interesting since they modify overall feed intake and not only feed intake kinetics.

\section{The effect of nutrients on short-term feed intake control}

The reticulo-rumen forms a very effective fermenter capable of rapidly digesting the carbohydrate compounds found in plant fibre for which ruminants have no specific enzymic system. The rumen digestion of carbohydrates essentially produces short-chain fatty acids, or volatile fatty acids (VFA), with two to six $\mathrm{C}$ atoms, mainly acetic, propionic and butyric acids, and to a lesser extent valeric and caproic acids and their isomers. Substances that are not degraded in the rumen are digested in the abomasum and the intestine, essentially as they are in single-stomached animals. The relative proportions of these final digestion products vary considerably according to the composition of the diet.

VFA are very quickly metabolized when they pass through the rumen wall. Acetic and butyric acids mainly form ketonic and acetate substances in the blood, whereas propionic acid is almost totally converted into lactate (in the ruminal epithelium) and into glucose (in the liver). In ruminants, unless they are given a special diet, there is little glucose digested in the intestine. Glucose is primarily produced by hepatic gluconeogenesis. Ruminant livers use virtually no blood glucose.

\section{Energy nutrients}

Carbohydrates (i.e. soluble sugars, starch, hemicellulose and cellulose) ingested by ruminants may either be converted into VFA, mainly in the reticulo-rumen (a little in the omasum and in the large intestine) or, to a lesser extent, into glucose in the intestine, when starch is not digested microbially in the rumen.

Volatile fatty acids. VFA are the main energy source for ruminants, generally accounting for 50-75\% of energy digested. Their production through fermentation increases very rapidly when feed arrives in the rumen. These two characteristics explain why VFA were soon considered to play an important role in satiation.

Many experiments have shown that intraruminal infusion of a VFA mixture with a composition similar to that normally found in the rumen causes a decrease in feed intake during the course of a meal. Feed intake is inversely proportional to the amount of VFA infused. Major infusion experiments have shown that feed intake response varies with the type of VFA infused (Faverdin et al. 1995), in the following decreasing order: acetate $>$ VFA mixture > propionate $>$ butyrate. For a given level of energy infused, feed intake response is inversely proportional to the size of the molecule. Osmolarity in the rumen, however, seems to be a major satiation factor, as salt infusion studies have shown (Ternouth \& Beattie, 1971; Bergen, 1972). This observation suggests that the VFA action cue may be of an osmotic nature. Comparing the effects of osmolarity and VFA has revealed considerable similarities (Grovum, 1995). In Baile's work (Baile \& McLaughlin, 1970), which resulted in the highest intake responses, the authors also noted a significant effect on water consumption. The nature of the rumen receptors remains to be determined (Forbes \& Barrio, 1992), and there is no biological proof of the existence of osmoreceptors in rumen walls that are sensitive to physiological variations in osmotic pressure (Carter \& Grovum, 1990). The role of an osmotic cue, however, would be very similar. The increase in osmotic pressure may harm both the ruminant and the functioning of the rumen, since microbial cellulolytic activity is considerably reduced when the osmotic pressure of the incubation medium is increased (Bergen, 1972).

The effects of VFA mixtures are sometimes greater than those of an iso-osmotic saline $(9 \mathrm{~g} \mathrm{NaCl} / \mathrm{l})$ control sample (Engku Azahan \& Forbes, 1992; Faverdin et al. 1992; Faverdin \& Peyraud, 1994). It is possible that the effect of the VFA is not merely osmotic in nature. Among the various VFA, propionate seems to play a major and special role 
(Baile \& Mayer, 1969; Frobish \& Davis, 1976; Farningham $\&$ White, 1993). The injection of local anaesthetics into the rumen eliminates the effects of acetate and butyrate infusions, but not those of propionate infusions (Martin \& Baile, 1972). Infusion into the liver seems to reduce appetite whereas infusion into the jugular vein has no effect (Anil \& Forbes, 1980). Furthermore, lesions of the nerves of the hepatic plexus eliminate the effect of propionate infused into the portal vein. Strangely, the response in the mesenteric veins seems to be greater than that in the portal vein (Leuvenink et al. 1995). The most recent work shows clearly that this effect is independent of the osmotic effects related to the infusion (Farningham \& White, 1993; Leuvenink et al. 1995).

With more physiological doses or with saline control solutions, the effect of VFA infusions tends to disappear (De Jong, 1981; Quigley \& Heitmann, 1991; Grovum, 1995). It seems, however, that animals become increasingly sensitive to VFA infusions with higher feed intake levels and therefore higher internal VFA production (Faverdin, 1990; Faverdin et al. 1992).

These various satiation cues may combine and, at least partially, have a cumulative effect over the short term. Thus, ruminal infusions of propionate and acetate result in a greater decrease in feed intake than each of the nutrients infused alone (Mbanya et al. 1993). This finding is in keeping, as with a dose effect, with detection by osmoreceptors. However, the same cumulative effect may be seen with different types of satiation cues such as rumen fill and VFA infusion (Adams \& Forbes, 1981).

Far from controlling feed intake according to needs, short-term VFA satiation mechanisms, above all, make it possible to evaluate the size of the meal and prevent excesses that could be detrimental to the proper functioning of the rumen or even the ruminant's health. It is probable, however, that propionate plays a special role among the various VFA as a feed intake control cue. Thus, it could help limit the intake of diets rich in feed concentrates.

Glucose. Intestinal glucose represents a relatively minor energy source in normal ruminant diets. Only the presence of a large amount of starch with low rumen degradability would result in large amounts of glucose. Given the important roles that glucose and insulin play in rats and human subjects, many authors have tried to detect similar effects in ruminants. In the late 1950s, Manning et al. (1959) infused glucose intravenously into adult ewes for $2 \mathrm{~h}$ and observed no changes in feed intake or in eating behaviour. These results were rapidly confirmed (Dowden \& Jacobson, 1960). Since then, intravenous or intraperitoneal infusions performed on various ovine and bovine species at various doses and times (Holder, 1963; Simkins et al. 1965; Frobish \& Davis, 1976; Hikosaka et al. 1979) have revealed no effect of glucose on feed intake.

Intravenous infusions of insulin increase the use of glucose by tissues in ruminants as in single-stomached animals. This phenomenon also often causes a slight decrease in glycaemia during meals, since glucose use increases more rapidly than its arrival during the meal as a result of digestive absorption or gluconeogenesis. Intravenous infusion of insulin induces a slight decrease in feed intake during the $30 \mathrm{~min}$ following the injection (the phase during which glucose is most rapidly used). However, this very short-term effect is generally compensated for during the following $1 \mathrm{~h}$ by an increase in feed intake (Faverdin, 1985; Bareille \& Faverdin, 1996). Conversely, large injections of insulin result in prolonged hypoglycaemia that increases feed intake to some extent (Houpt, 1974). These side-effects of insulin and glucose (Dulphy \& Faverdin, 1987) in ruminants are similar to effects observed in singlestomached animals, but are much less severe (Le Magnen, 1985). However, it is probable that the low variations in glycaemia and exogenous glucose under actual feeding conditions limit the effect of these mechanisms.

Lipids. Lipids form a small proportion of the energy nutrients ingested by ruminants, since roughage tends to contain relatively little lipid. Most lipids are hydrolysed in the rumen and the long-chain fatty acids thus released are largely hydrogenated when they are not protected by special treatments. Fatty acids are absorbed by the intestine in quantities similar to those ingested, but they have a very different composition (following hydrogenation and conversion to microbial lipids). Their short-term effects can be studied by intravenous infusion, since any rapid increase in lipids is primarily due to the mobilization of body reserves. Studies related to this subject (Vandermeerschen-Doize \& Paquay, 1984; Bareille \& Faverdin, 1996) have revealed that lipid infusion depresses feed intake. This response is very fast and synchronous with infusion, but it remains limited. The response to exogenous lipids, such as Intralipid infusion, is different however from that observed by the mobilization of body lipids using such lipolytic substances as $\beta$-adrenergic agonists (Bareille \& Faverdin, 1996). This response is due to the fact that during the lipolysis phase caused by the lipolytic agents the concentration of free fatty acids increases very rapidly, with no effect on appetite. It is only several hours later that feed intake decreases, this decrease possibly continuing after the mobilization phase. The effect of free fatty acids on appetite, therefore, does not seem to be direct, and the mechanisms involved have not been clearly identified in ruminants.

\section{Nitrogenous nutrients}

The microbial population is able to digest all nutrients in relatively large proportions. This is the case for protein, which forms $\mathrm{NH}_{3}$. Microbes, however, can also use $\mathrm{NH}_{3}$ to make their own amino acids and proteins; thus the amino acids arriving in the cow's duodenum are different in proportion and in nature from those in the ingested protein. This adaptation of $\mathrm{N}$ and the ability to use non-protein- $\mathrm{N}$ are therefore major points of difference from single-stomached animals. This process means that proteins arrive in the intestine much later than the time of ingestion, and may be considered to have a more medium-term action.

Rumen degradation on the other hand rapidly causes $\mathrm{NH}_{3}$ to form in the rumen, and this may constitute a major shortterm cue. $\mathrm{NH}_{3}$ in the rumen enables microbes to carry out protein synthesis, but it is absorbed very rapidly through the rumen wall and may become toxic in large doses when the liver's detoxification capacity is exceeded. This process may explain the decrease in feed intake observed after infusion of ammonium salts into the goat rumen (Conrad et al. 1977). 
However, large doses must be administered to obtain these responses and adding $\mathrm{NH}_{3}$ to grass silage in doses near those observed in practice causes no modification in behaviour and no decrease in feed intake in sheep (Van Os et al. 1995).

\section{Short-term response limits}

Experimental feeding of final digestion products to ruminants poses many methodological problems due to the short length of the $\mathrm{C}$ chains, which means that substantial amounts must be provided to reach a significant energy level. When biosystem conditions are not disrupted, there is generally no effect on feed intake (De Jong, 1981).

To avoid problems associated with infusion methodology, another possibility is to add directly into the rumen a feed that ferments rapidly (using an artificial saliva to replace that which would have normally accompanied ingestion) for a short period. Using this methodology, no effect on the satiation response for the meal studied was observed, either during the meal or during the $4 \mathrm{~h}$ preceding the meal (Faverdin et al. 1999). However, more than $12 \mathrm{~h}$ after this treatment, cows increased the intensity of their satiation response during main meals of their usual diet, although no further treatment was administered. The cows assimilate the characteristics of a particular diet after analysing all the consequences of a meal's post-digestive characteristics. After one or more experiences, diets are evaluated according to their sensory characteristics at the start of the meal and animals anticipate the expected consequences by satiation responses of varying intensity. They cannot do this rapidly when the feed is added directly to the rumen (Baumont et al. 1994).

Recent work by Provenza and his team (Provenza, 1995) clearly shows the important role that post-ingestive cues play in the learning of diet preference, and how the diet's sensory characteristics are used to identify it, as had been observed in single-stomached animals (Booth, 1992). Experiments performed over a period of only a few hours have been unable to account for these learning mechanisms, which control feed intake or diet preference over a longer period. A treatment that has no effect over the very short term may modify the animal's feed intake over the long term through a learning process. Conversely, a nutrient's very high short-term impact on feed intake, due to a disruption of the animal's equilibrium, may disappear after several days of treatment if the animal succeeds in adapting to this disequilibrium. In ruminants, the satiation process seems to be largely determined at the start of the meal, once the diet has been identified. Associations between nutrients and hormonal secretions certainly play a decisive role in the memorization and learning of the necessary behavioural response to a given diet. The role of cholecystokinin in these processes has already been clearly observed (Farningham et al. 1993; Berthelot et al. 1996). After learning, feed intake control responses to different nutrients may therefore be different from responses observed over the short term.

Short-term effects of nutrients on the control of feed intake may be found in ruminants, but they seem to be minor. Nutrients have a direct feedback effect on feed intake primarily when they disrupt the animal's homeostasis. The main mechanisms seem to involve osmotic pressure equilibrium, rumen distension, homeothermy and acid-base equilibrium in the blood and the rumen. These mechanisms work to preserve the animal's short-term equilibrium. When they are triggered minimally or not at all, there is generally little effect on feed intake. However, short-term cues may be involved in the learning mechanisms that enable diet evaluation, and thus have a lasting effect on feed intake.

\section{The effects of nutrients on medium- and long-term control of feed intake}

Medium- and long-term feed intake responses always involve complex mechanisms. In ruminants they are even more complex, since there are two types of nutritional equilibria: the equilibrium of the rumen ecosystem and the metabolic equilibrium of the ruminant itself.

\section{Energy nutrients}

Volatile fatty acids. VFA infusions administered in order to study effects on feed intake have generally been designed to favour short-term response. However, infusions of a VFA mixture for 2 weeks show that the substantial effects observed during the first few days in lactating animals tend to disappear after 2 weeks of infusion (Faverdin et al. 1992).

Thus, after experience, responses to repeated VFA infusions may evolve. When excess propionate in the rumen is associated, through learning, with a particular smell applied to a particular diet, the conditioned preference for this diet decreases in comparison with the same diet with a different smell (Ralphs et al. 1995). This aversive response only occurs with large amounts of propionate. Furthermore, the same response is obtained with excess salt (Villalba \& Provenza, 1996). It is possible that the negative effects of the disequilibrium caused by hyperosmotic infusions are associated with a state of discomfort, perhaps a 'nauseous' feeling. When antiemetic drugs are used to treat a $\mathrm{LiCl}-$ induced aversion, they neutralize the effect of $\mathrm{LiCl}$ on the appetite (Provenza et al. 1994). It would be interesting to study the effects of these drugs during ruminal infusions of high VFA doses. However, lambs show a clear preference for diets associated with low-propionate doses in the rumen (Villalba \& Provenza, 1996). The mechanisms of this preference are not yet known, but they allow the ruminant to select diets containing the most gluconeogenetic substances.

Glucose. Extended infusions of glucose into the duodenum have no effect on feed intake in dairy cows (Faverdin et al. 1992). Unlike single-stomached animals, glucose receptors could not be found in the ruminant duodenum. Adapting the diet to increase glucose in the intestine therefore has no effect on feed intake. The same is true for large doses of starch when the intestinal enzymic system is present. Over the long term, a starch-rich diet that is not degraded in the rumen is generally more readily ingested than a diet with an equivalent energy value but which is primarily and rapidly degraded in the rumen. This finding is consistent with the assumption that ruminants are more sensitive to satiation cues from the rumen than to those from intestinal digestion, particularly with respect to glucose.

Furthermore, it seems that ruminants detect and develop a preference for sweetened diets. For example, among several 
types of feed additives or control samples, cows show a preference for diets to which sucrose has been added (15 g/kg DM content; Nombekela et al. 1994). Similarly, after a period of learning, sheep prefer a diet when it is associated with the force-feeding of glucose, even though glucose is highly fermented in the rumen (Ralphs et al. 1995). The mechanisms of this preference for sugar in ruminants have yet to be understood. There are few practical applications, since this preference for sweetness does not enable feed intake to be increased over the long term (Nombekela \& Murphy, 1995).

In ruminants, intestinal glucose does not seem to have a satiation effect. It is undoubtedly by modifying the area of the digestive system where energy is digested, rather than by modifying palatability, that diets rich in intestinal glucose may contribute to increasing feed intake, even if ruminants show a preference for sweet feeds when they can choose.

Lipids. There are few lipids in ruminant feed. However, adding lipids directly to feed or by extended infusion has been widely studied for dairy cows, in order to increase the diet's energy supply and reduce the mobilization of reserves. Indeed, lactating animals release large quantities of lipids into milk (over $1 \mathrm{~kg} / \mathrm{d}$ at the start of lactation) which are mostly synthesized from VFA produced in the rumen and long-chain fatty acids produced by the mobilization of adipose tissue.

Lipids added to the duodenum by extended infusion generally reduce feed intake (Hagemeister et al. 1988; Gagliostro \& Chilliard, 1991; Chilliard et al. 1993; Doreau \& Chilliard, 1997). These responses are significant for rather low doses of 300-500 g lipids/d, with a reduction in intake of about $2 \mathrm{~kg} \mathrm{DM}$, or about $10 \%$ of daily intake. Although effects are consistent with the results obtained from intravenous infusions of Intralipid over the short term, these infusions had no effect beyond $3 \mathrm{~d}$ in sheep (Vandermeerschen-Doize \& Paquay, 1984). However, generally speaking, decreases in feed intake are greater than the energy equivalent infused.

When lipids are ingested or directly infused into the rumen, the decrease in feed intake is even greater (Chilliard et al. 1993). These negative effects are proportional to the polyunsaturated fatty acid content of the lipids. These effects on feed intake have long been attributed to the negative effects of lipid infusion on rumen digestion (Michalet-Doreau et al. 1997) or to palatability problems associated with high-fat diets. However, very great decreases in feed intake $(-18 \%)$ are observed during intraruminal infusion of fish oil (Doreau \& Chilliard, 1997), although indices of digestion may even be improved. It is possible that the hydrogenation of fats forms substances that have specific effects on feed intake control, but no such substances have yet been identified.

\section{Nitrogenous nutrients}

Nitrogenous nutrients are, over the long term, just as important for rumen microbes as for the ruminant itself. Very generally speaking, feed intake increases with the amount of crude protein $(\mathrm{N} \times 6 \cdot 25)$ in the diet. For cows starting lactation, feed intake increases by $0.4 \mathrm{~kg}$ DM (about $2-2.5 \%$ ) for each $\mathrm{g}$ crude protein $/ \mathrm{kg} \mathrm{DM}$ added to the diet
(Journet et al. 1983). There are many mechanisms that can explain this increase. These mechanisms may involve digestive aspects, particularly those relating to the rumen, nutritional aspects related to the ruminant, or a combination of the amount and type of protein intake (i.e. palatability and amino acid equilibrium).

Increase in nitrogen that is degradable in the rumen. The first explanation, and that most frequently advanced, concerns the effect of the crude protein on microbial activity and the digestion of $\mathrm{N}$ in the rumen. Many studies have shown an improvement in feed digestibility and microbial activity when crude protein that is degradable in the rumen is added. Faster and more complete digestion of the feed by microbes apparently reduces the fill of the feed in the rumen, and thus enables an increase in feed intake. Unfortunately, this hypothesis, which seems plausible with very poor roughage, is not totally convincing for other diets. There seems to be a greater response to adding crude protein when diets are rich in concentrates $(5 \%$ increase or more in feed intake for each $\mathrm{g}$ crude protein $/ \mathrm{kg}$ added to the diet) than with high-roughage diets (Cowan et al. 1981; Faverdin et al. 1998), although rumen fill problems are less severe with these diets. Effects on rumen functioning may stimulate appetite independently of effects on rumen fill. Ruminants rapidly learn to prefer diets that improve the functioning of the rumen. For example, after a conditioning period, lambs always prefer diets associated with the presence of casein in the rumen, whereas this is not always the case with high doses of urea, which may result in excess $\mathrm{NH}_{3}$ (Villalba \& Provenza, 1997).

The effect of protein degradability. It is also possible that the appetite of ruminants is stimulated by a larger intake of digestible protein. By using protein sources of varying degradability in the rumen, the use of protein may be divided between the rumen microbial population and the ruminant itself. Many studies have been performed with dairy cows by comparing diets with identical amounts of crude protein but of different degradability. The variations in degradability caused by the usual treatments (i.e. heating, protein type and substitution with non-protein-N) have no effect on feed intake (Vérité \& Journet, 1975; Mielke \& Schingoethe, 1981; Netemeyer et al. 1982; Kung \& Huber, 1983; Annexstad et al. 1987; Robinson \& Kennelly, 1988; Broderick et al. 1990; Scott et al. 1991; Grummer et al. 1996). In some tests, where proteins are protected from degradation in the rumen by formaldehyde tanning, feed intake is increased (Vérité \& Journet, 1977; Lundquist et al. 1986; Baker et al. 1996). Fish and certain animal meals which contain a large amount of protein that is not easily degraded may not appeal to ruminants (Spain et al. 1990; Atwal \& Erfle, 1992), and their effect on feed intake cannot be directly related to an increase in protected protein intake.

The effect of post-rumen infusion of protein. Adding protein directly to the abomasum or to the duodenum by continuous infusion generally has no significant effect on feed intake (Broderick et al. 1970; Vik-Mo et al. 1974; Spires et al. 1975; Clark et al. 1977; Barry, 1980; Rogers et al. 1984; Seymour et al. 1990; Choung \& Chamberlain, $1993 a, b)$. Only a few tests with very poor roughage (Egan, 1965), grass or grass silage show positive effects (even very short-term effects) which sometimes 
seem to be due to hydromineral equilibrium problems (Bryant et al. 1970).

The effect of amino acid equilibrium. The specific effects of amino acids on feed intake in ruminants seem to be much fewer than those in single-stomached animals (Forbes, 1995). Although there is variation in the composition of intestinal amino acids (Rulquin \& Vérité, 1993), this variation is less than that in single-stomached animals, due to the large proportion of microbial protein in intestinal protein flows. It is therefore difficult to increase the proportion of an amino acid other than by duodenal or intravenous infusion, or by providing protection against rumen degradation. The availability of protected methionine and lysine now makes it easy to increase the intake of these two amino acids. However, at the levels at which they are usually used (i.e. $6-30 \mathrm{~g} / \mathrm{d}$ for a lactating dairy cow), there is generally no significant effect on feed intake (Broderick et al. 1970; Yang et al. 1986; Xu et al. 1998), no more than that with duodenal or intravenous arginine infusions (Vinci et al. 1988). On the other hand, increasing methionine intake in sheep seems to stimulate appetite in many cases (Barry, 1976). In general, the effects of post-rumen additions of protein and the intestinal amino acid equilibrium do not explain the effects of feed protein content on feed intake.

Studies of feed preferences have shown that singlestomached animals are able to balance their diet to meet their amino acid requirements when they are offered a choice between several feeds containing different amounts of amino acids. The protein requirements of a dairy cow change considerably during lactation. When cows are offered the choice between two diets with different protected-protein contents throughout their lactation, they prefer the high-protein diet, but the proportion ingested of each of the two diets offered does not change (Tolkamp et al. 1998). Similarly, ewes prefer high-N diets independently of their protein requirements (Cooper et al. 1994). There are no studies that currently indicate specific appetites related to amino acid equilibrium in ruminants.

Ruminants mainly select feed based on the amount of crude protein, generally showing a preference for diets high in high-quality degradable N. Controlling feed intake through $\mathrm{N}$ apparently serves to meet the animal's requirements primarily by optimizing the functioning of the rumen.

\section{Conclusion}

In ruminants, feed intake is mostly controlled by cues triggered by the presence of feed in the rumen. Cues sent from subsequent digestion stages (abomasum and intestines) are undoubtedly less important, as Baile \& Mayer's (1967) experiments have shown. The distension of the rumen and the various chemical or biochemical cues triggered by rumen digestion enable ruminants to control their short-term feed intake. Nutritional signals perceived over the short term are not directly related to the control of energy consumption. Over the longer term, ruminants seem able to select feed both to optimize the functioning of their rumen and to satisfy the nutritional equilibrium the organism requires. The energy consumption of ruminants may greatly exceed their requirements, and very rapid weight gains are possible with diets rich in feed concentrates. This finding tends to contradict energy control theories which assume that energy consumption does not increase when requirements are satisfied. The mechanisms that specifically control a ruminant's nutrient flows are not clearly understood, but new theories propose some interesting possibilities (Tolkamp \& Ketelaars, 1992; Illius \& Jessop, 1996). It is possible that annual variations in the nature of the availability and quality of roughage serve naturally to limit nutrient intake over the year.

The preference of ruminants for nutritional equilibria that facilitate rumen digestion may explain the good correlation between rate of feed intake and digestibility. In addition to the mechanical view of rumen fill that is associated with this improved digestibility, what may be most important in determining ruminant preferences and the feed intake levels of various diets is probably this adjustment to achieve rumen equilibrium.

\section{References}

Adams GB \& Forbes JM (1981) Additivity of effects of ruminal acetate and either portal propionate or rumen distension on food intake in sheep. Proceedings of the Nutrition Society 40, 44A.

Anil MH \& Forbes JM (1980) Feeding in sheep during intraportal infusions of short chain fatty acids and the effect of liver denervation. Journal of Physiology 298, 407-414.

Annexstad RJ, Stern MD, Otterby DE, Linn JG \& Hansen WP (1987) Extruded soybeans and corn gluten meal as supplemental protein sources for lactating dairy cattle. Journal of Dairy Science 70, 814-822.

Atwal AS \& Erfle JD (1992) Effects of feeding fish meal to cows on digestibility, milk production, and milk composition. Journal of Dairy Science 75, 502-507.

Baile CA \& McLaughlin CL (1970) Feed intake of goats during VFA injections into four gastric areas. Journal of Dairy Science 53, 1058-1063.

Baile CA \& Mayer J (1967) Intragastric injections of liquid diet, water and acetate and meal patterns of goats. American Journal of Physiology 213, 387-392.

Baile CA \& Mayer J (1969) Depression of feed intake of goats by metabolites injected during meals. American Journal of Physiology 217, 1830-1836.

Baker MJ, Amos HE, Nelson A, Williams CC \& Froetschel MA (1996) Undegraded intake protein: effects on milk production and amino acid utilization by cows fed wheat silage. Canadian Journal of Animal Science 76, 367-376.

Bareille N \& Faverdin P (1996) Modulation of the feeding response of lactating dairy cows to peripheral insulin administration with or without a glucose supply. Reproduction Nutrition Development 36, 83-93.

Barry TN (1976) Effects of intraperitoneal injections of DL-methionine on the voluntary intake and wool growth of sheep fed sole diets of hay, silage and pasture differing in digestibility. Journal of Agricultural Science, Cambridge 86, 141-149.

Barry TN (1980) Responses to abomasal infusions of casein plus methionine in lactating ewes fed fresh pasture. New Zealand Journal of Agricultural Research 23, 427-431.

Baumont R, Daveau O \& Perpère C (1994) A trial to quantify the roles of ruminal and oropharyngeal signals in the control of food intake by cows. Proceedings of the Society for Nutritional Physiology 3, 122.

Bergen WG (1972) Rumen osmolality as a factor in feed intake control of sheep. Journal of Animal Science 34, 1054-1060.

Berthelot V, Belzung C, Meunier-Salaun MC, Nowak R \& Picard M (1996) Cholecystokinin A receptor antagonist inhibits 
feed memory in Japanese quail. Physiology and Behavior 60, 575-579.

Booth DA (1992) Integration of internal and external signals in intake control. Proceedings of the Nutrition Society 51, 21-28.

Broderick GA, Kowalczyk T \& Satter LD (1970) Milk production response to supplementation with encapsuled methionine per os or casein per abomasum. Journal of Dairy Science 53, 1714-1721.

Broderick GA, Ricker DB \& Driver LS (1990) Expeller soybean meal and corn by-products versus solvent soybean meal for lactating dairy cows fed alfalfa silage as sole forage. Journal of Dairy Science 73, 453-462.

Bryant AM, Titchen DA \& Reid CSW (1970) Some effects on food intake of infusions of amino acid-containing materials. Proceedings of the New Zealand Society for Animal Production 30, 227-239.

Campling RC \& Balch CC (1961) Factors affecting the voluntary intake of food by cows. 1. Preliminary observations of the effects, on the voluntary intake of hay, of changes in the amount of reticulo-ruminal contents. British Journal of Nutrition 15, 523-530.

Carter RR \& Grovum WL (1990) A review of the physiological significance of hypertonic body fluids on feed intake and ruminal function: salivation, motility, and microbes. Journal of Animal Science 68, 2811-2832.

Chilliard Y, Doreau M, Gagliostro G \& Elmeddah Y (1993) Addition de lipides protégés (encapsulés ou savons de calcium) à la ration de vaches laitières. Effets sur les performances et la composition du lait (Protected (encapsulated or calcium salts) lipids in dairy cow diets. Effects on production and milk composition). INRA Productions Animales 6, 139-150.

Choung JJ \& Chamberlain DG (1993a) The effects of abomasal infusions of casein or soyabean-protein isolate on the milk production of dairy cows in mid-lactation. British Journal of Nutrition 69, 103-115.

Choung JJ \& Chamberlain DG (1993b) Effects of addition of lactic acid and post-ruminal supplementation with casein on the nutritional value of grass silage for milk production in dairy cows. Grass Forage Science 48, 380-386.

Clark JH, Spires HR, Derrig RG \& Bennink MR (1977) Milk production, nitrogen utilization and glucose synthesis in lactating cows infused postruminally with sodium caseinate and glucose. Journal of Nutrition 107, 631-644.

Conrad HR, Baile CA \& Mayer J (1977) Changing meal patterns and suppression of feed intake with increasing amounts of dietary nonprotein nitrogen in ruminants. Journal of Dairy Science 60, 1725-1733.

Cooper SDB, Kyriazakis I \& Oldham JD (1994) The effect of late pregnancy on the diet selections made by ewes. Livestock Production Science 40, 263-275.

Cowan RT, Reid GW, Greenhalgh JFD \& Tait CAG (1981) Effects of feeding level in late pregnancy and dietary protein concentration during early lactation on food intake, milk yield, liveweight change and nitrogen balance of cows. Journal of Dairy Research 48, 201-212.

De Jong A (1981) Regulation of food intake in the goat: circulating metabolites and hormones in relation to eating. $\mathrm{PhD}$ Thesis, University of Groningen.

Doreau M \& Chilliard Y (1997) Effects of ruminal or postruminal fish oil supplementation on intake and digestion in dairy cows. Reproduction Nutrition Development 37, 113-124.

Dowden DR \& Jacobson DR (1960) Inhibition of appetite in dairy cattle by certain intermediate metabolites. Nature 188, 148-149.

Dulphy JP \& Faverdin P (1987) L'ingestion alimentaire chez les ruminants: modalités et phénomènes associés (Feed intake in ruminants: activities and related events). Reproduction Nutrition Development 27, 129-155.
Egan AR (1965) Nutritional status and intake regulation in sheep. II. The influence of sustained duodenal infusions of casein or urea upon voluntary intake of low-protein roughages by sheep. Australian Journal of Agricultural Research 16, 451-462.

Engku Azahan EA \& Forbes JM (1992) Effects of intraruminal infusions of sodium salts on selection of hay and concentrate foods by sheep. Appetite 18, 143-154.

Farningham DAH, Mercer JG \& Lawrence CB (1993) Satiety signals in sheep: involvement of $\mathrm{CCK}$, propionate, and vagal CCK binding sites. Physiology and Behavior 54, 437-442.

Farningham DAH \& White CC (1993) The role of propionate and acetate in the control of food intake in sheep. British Journal of Nutrition 70, 37-46.

Faverdin P (1985) Régulation de l'ingestion des vaches laitières en début de lactation: variations au cours du nychtémère de l'activité alimentaire, des métabolites sanguins et de l'insulinémie et étude du rôle de l'insuline (Regulation of feed intake in early lactating dairy cows: daily pattern of feeding behaviour, blood metabolites and insulin; the role of insulin). $\mathrm{PhD}$ Thesis, Institut National Agronomique Paris Grignon.

Faverdin P (1990) Effets d'infusion d'un mélange complet d'acides gras volatils en cours de repas sur la prise alimentaire de vaches taries ou en lactation (Effects of infusion of a complete mixture of volatile fatty acids during a meal on feed intake of dry and lactating cows). Reproduction Nutrition Development, Suppl. 2, $213 \mathrm{~s}-214 \mathrm{~s}$.

Faverdin P, Bareille N \& Vérité R (1999) Effect of timing of rumen energy supply on feed intake control in lactating dairy cows. Journal of Dairy Science (In the Press).

Faverdin P, Baumont R \& Ingvartsen KL (1995) Control and prediction of feed intake in ruminants. In Recent Developments in the Nutrition of Herbivores. Proceedings of the Fourth International Symposium on the Nutrition of Herbivores, pp. 95-120 [M Journet, E Grenet, MH Farce, M Theriez and C Demarquilly, editors]. Paris: INRA Editions.

Faverdin P, Delaby L, Vérité R \& Marquis B (1998) Effet de la teneur en protéines et en aliments concentrés d'une ration complète à base d'ensilage de maïs sur l'ingestion et la production laitière de vaches laitières en début de lactation (Effect of protein and concentrate content of a complete maizesilage-based diet on feed intake and milk production of dairy cows in early lactation). Rencontres Recherches Ruminants $\mathbf{5}$, 263.

Faverdin P \& Peyraud JL (1994) Effects of kinetics of volatile fatty acids infusion into the rumen on feed intake in lactating cows. Proceedings of the Society for Nutritional Physiology 3, 126.

Faverdin P, Richou B \& Peyraud JL (1992) Effects of digestive infusions of volatile fatty acids or glucose on food intake in lactating or dry cows. Annales de Zootechnie 41, 93.

Forbes JM (1995) Voluntary Food Intake and Diet Selection in Farm Animals. Wallingford: CAB International.

Forbes JM \& Barrio JP (1992) Abdominal chemo- and mechanosensitivity in ruminants and its role in the control of food intake. Experimental Physiology 77, 27-50.

Frobish RA \& Davis CL (1976) Effects of abomasal infusion of glucose and propionate on milk yield and composition. Journal of Dairy Science 60, 204-209.

Gagliostro G \& Chilliard Y (1991) Duodenal rapeseed oil infusion in early and midlactation cows. 4. In vivo and in vitro adipose tissue lipolytic responses. Journal of Dairy Science $\mathbf{7 4}$, $1830-1843$.

Grovum WL (1995) Mechanisms explaining the effects of short chain fatty acids on feed intake in ruminants - osmotic pressure, insulin and glucagon. In Ruminant Physiology: Digestion, Metabolism, Growth and Reproduction: Proceedings of the Eighth International Symposium on Ruminant Physiology, 
pp. 173-197 [WV Engelhardt, S Leonhard-Marek, G Breves and D Giesecke, editors]. Stuttgart: Ferdinand Enke Verlag.

Grummer RR, Slark K, Bertics SJ, Luck ML \& Barmore JA (1996) Soybeans versus animal sources of rumen-undegradable protein and fat for early lactation dairy cows. Journal of Dairy Science 79, 1809-1816.

Hagemeister H, Precht D \& Barth CA (1988) Zum Transfer von Omega-3-Fettsäuren in das Milchfett bei Kühen (Transfer of omega-3 fatty acids into milk fat in dairy cows). Milchwissenschaft 43, 153-158.

Hikosaka K, Sasaki Y \& Tsuda T (1979) Effects of glucose, insulin and FFA on food intake in the sheep. Annales de Recherches Vétérinaires 10, 237-239.

Holder JM (1963) Chemostatic regulation of appetite in sheep. Nature 200, 1074-1075.

Houpt TR (1974) Stimulation of food intake in ruminants by 2-deoxy-D-glucose and insulin. American Journal of Physiology 227, 161-167.

Illius AW \& Jessop NS (1996) Metabolic constraints on voluntary intake in ruminants. Journal of Animal Science 74, 3052-3062.

Jarrige R, Dulphy JP, Faverdin P, Baumont R \& Demarquilly C (1995) Activités d'ingestion et de rumination (Eating and rumination). In Nutrition des Ruminants Domestiques Ingestion et Digestion (The Nutrition of Domestic Ruminants Intake and Digestion), pp. 123-181 [R Jarrige, Y Ruckebush, C Demarquilly, MH Farce and M Journet, editors]. Paris: INRA Editions.

Journet M, Champredon C, Pion R \& Vérité R (1983) Physiological basis of the protein nutrition of high producing cows. Critical analysis of the allowances. Protein Metabolism and Nutrition. 4th International Symposium. European Association for Animal Production Publication no. 31, pp. 433-448. Paris: INRA.

Kung L Jr \& Huber JT (1983) Influence of nonprotein nitrogen and protein of low rumen degradability on nitrogen flow and utilization in lactating dairy cows. Journal of Dairy Science 66, 227-234.

Le Magnen J (1985) Hunger. Cambridge: Cambridge University Press.

Leuvenink HGD, Bleumer EJB, Kruys P \& Bongers LJGM (1995) Propionate induced effects on feed intake and blood parameters in sheep. Annales de Zootechnie 44, 244.

Lundquist RG, Otterby DE \& Linn JG (1986) Influence of formaldehyde-treated soybean meal on milk production. Journal of Dairy Science 69, 1337-1345.

Manning R, Alexander GI, Krueger HM \& Bogart R (1959) The effect of intravenous glucose injections on appetite in adult ewes. American Journal of Veterinary Research 20, 242-246.

Martin FH \& Baile CA (1972) Feed intake of goats and sheep following acetate or propionate injections into rumen, ruminal pouches and abomasum as affected by local anesthetics. Journal of Dairy Science 55, 606-613.

Mbanya JN, Anil MH \& Forbes JM (1993) The voluntary intake of hay and silage by lactating cows in response to ruminal infusion of acetate or propionate, or both, with and without distension of the rumen with a balloon. British Journal of Nutrition $\mathbf{6 9}$, 713-720.

Michalet-Doreau B, Martin C \& Doreau M (1997) Optimisation de la digestion des parois végétales dans le rumen: quantification des ineractions digestives (Optimisation of fibre ruminal digestion: interactions of fibre digestion with other components). Rencontres Recherches Ruminants 4, 103-112.

Mielke CD \& Schingoethe DJ (1981) Heat-treated soybeans for lactating cows. Journal of Dairy Science 64, 1579-1585.

Netemeyer DT, Bush LJ, Ward JW \& Jafri SA (1982) Effect of heating soybean meal for dairy cows. Journal of Dairy Science 65, 235-241.
Nombekela SW \& Murphy MR (1995) Sucrose supplementation and feed intake of dairy cows in early lactation. Journal of Dairy Science 78, 880-885.

Nombekela SW, Murphy MR, Gonyou HW \& Marden JI (1994) Dietary preference in early lactation cows as affected by primary tastes and some common feed flavors. Journal of Dairy Science 77, 2393-2399.

Provenza FD (1995) Role of learning in food preferences of ruminants: Greenhalgh and Reid revisited. In Ruminant Physiology: Digestion, Metabolism, Growth and Reproduction: Proceedings of the Eighth International Symposium on Ruminant Physiology, pp. 233-247 [WV Engelhardt, S Leonhard-Marek, G Breves and D Giesecke, editors]. Stuttgart: Ferdinand Enke Verlag.

Provenza FD, Ortega-Reyes L, Scott CB, Lynch JJ \& Burritt EA (1994) Antiemetic drugs attenuate food aversions in sheep. Journal of Animal Science 72, 1989-1994.

Quigley JD \& Heitmann RN (1991) Effect of propionate and dietary energy on dry matter intake in sheep. Journal of Animal Science 69, 1178-1187.

Ralphs MH, Provenza FD, Wiedmeier RD \& Bunderson FB (1995) Effects of energy source and food flavor on conditioned preferences in sheep. Journal of Animal Science 73, 1651-1657.

Robinson PH \& Kennelly JJ (1988) Influence of intake of rumen undegradable protein on milk production of late lactation Holstein cows. Journal of Dairy Science 71, 2135-2142.

Rogers JA, Clark JH, Drendel TR \& Fahey GC (1984) Milk production and nitrogen utilization by dairy cows infused postruminally with sodium caseinate, soybean meal, or cottonseed meal. Journal of Dairy Science 67, 1928-1935.

Rulquin H \& Vérité R (1993) Amino acid nutrition of dairy cows: productive effects and animal requirements. In Recent Advances in Animal Nutrition, pp. 55-77 [PC Garnsworthy, editor]. Nottingham: Nottingham University Press.

Scott TA, Combs DK \& Grummer RR (1991) Effects of roasting, extrusion, and particle size on the feeding value of soybeans for dairy cows. Journal of Dairy Science 74, 2555-2562.

Seymour WM, Polan CE \& Herbein JH (1990) Effects of dietary protein degradability and casein or amino acid infusions on production and plasma amino acids in dairy cows. Journal of Dairy Science 73, 735-748.

Simkins KL, Suttle JW \& Baumgardt BR (1965) Regulation of food intake in ruminants: 4. effect of acetate, propionate, butyrate and glucose on voluntary food intake in dairy cattle. Journal of Dairy Science 48, 1635-1642.

Spain JN, Alvarado MD, Polan CE, Miller CN \& McGilliard ML (1990) Effect of protein source and energy on milk composition in midlactation dairy cows. Journal of Dairy Science 73, 445452 .

Spires HR, Clark JH, Derrig RG \& Davis CL (1975) Milk production and nitrogen utilization in response to postruminal infusion of sodium caseinate in lactating cows. Journal of Nutrition 105, 1111-1121.

Ternouth JH \& Beattie AW (1971) Studies of the food intake of sheep at a single meal. British Journal of Nutrition 25, 153-164.

Tolkamp BJ, Dewhurst RJ, Friggens NC, Kyriazakis I, Veerkamp RF \& Oldham JD (1998) Diet choice by dairy cows. 1. Selection for feed protein content during the first half of lactation. Journal of Dairy Science 81, 2657-2669.

Tolkamp BJ \& Ketelaars JJMH (1992) Toward a new theory of feed intake regulation in ruminants. 2. Costs and benefits of feed consumption: an optimization approach. Livestock Production Science 30, 297-317.

Van Os M, Dulphy JP \& Baumont R (1995) The effect of protein degradation products in grass silages on feed intake and intake behaviour in sheep. British Journal of Nutrition 73, 51-64. 
Vandermeerschen-Doize F \& Paquay R (1984) Etude du Contrôle à Long Terme des Ingestions Volontaires chez le Ruminant (The Long Term Control of Voluntary Feed Intake in the Ruminant). Namur: IRSIA, Presses Universitaire de Namur.

Vérité R \& Journet M (1975) Alimentation des vaches laitières avec de l'ensilage de maïs: Influence de la nature de l'ensilage, de la suralimentation énergétique et de la nature de la complémentation azotée. I.-Production laitière (Feeding of dairy cows maize silage: effects of the type of silage, level of energy and nature of nitrogen supplement. I.-Milk production). Annales de Zootechnie 24, 95-107.

Vérité R \& Journet M (1977) Utilisation des tourteaux traités au formol par les vaches laitières. II.- Effets sur la production laitière du traitement des tourteaux au formol et du niveau d'apport azoté au début de la lactation (Utilization of formaldehyde-treated oil meals by dairy cows. II. Milk production as affected by oil-meal treatment and protein supply during early lactation). Annales de Zootechnie 26, 183-205.

Vik-Mo L, Emery RS \& Huber JT (1974) Milk protein production in cows abomasally infused with casein or glucose. Journal of Dairy Science 57, 869-877.
Villalba JJ \& Provenza FD (1996) Preference for flavored wheat straw by lambs conditioned with intraruminal administrations of sodium propionate. Journal of Animal Science 74, 2362-2368.

Villalba JJ \& Provenza FD (1997) Preference for flavoured foods by lambs conditioned with intraruminal administration of nitrogen. British Journal of Nutrition 78, 545-561.

Vinci JL, Clark JH, Hurley WL \& Bahr JM (1988) Effects of abomasal or intravenous administration of arginine on milk production, milk composition, and concentrations of somatotropin and insulin in plasma of dairy cows. Journal of Dairy Science 71, 658-665.

Xu S, Harrison JH, Chalupa W, Sniffen C, Julien W, Sato H, Fujieda T, Watanabe K, Ueda T \& Suzuki H (1998) The effect of ruminal bypass lysine and methionine on milk yield and composition of lactating cows. Journal of Dairy Science 81, 1062-1077.

Yang CMJ, Schingoethe DJ \& Casper DP (1986) Protected methionine and heat-treated soybean meal for high producing dairy cows. Journal of Dairy Science 69, 2348-2357. 
